Komposisi:

Jurnal

Pendidikan

Bahasa, Sastra,

dan Seni

Volume XVII

Nomor 1

Maret 2016

Hal. 75-89

\section{EFFECT OF SOMATIC VISUAL INTELLECTUAL AUDITORY METHOD AND LEARNING MOTIVATION TO WRITING SKILL NUMBER OF DRAMA STUDENTS CLASS VIII MTSN KAYEK KALEK KECAMATAN LENGAYANG KABUPATEN PESISIR SELATAN \\ PENGARUH METODE SOMATIC AUDITORI VISUAL INTELLECTUAL DAN MOTIVASI BELAJAR TERHADAP KETERAMPILAN MENULIS NASKAH DRAMA SISWA KELAS VIII MTSN KAYU KALEK KECAMATAN LENGAYANG KABUPATEN PESISIR SELATAN}

\author{
Alvi Fitri Rahayu, Atmazaki, Abdurahman \\ Program Studi Magister Pendidikan Bahasa dan Sastra Indonesia \\ FBS Universitas Negeri Padang \\ Email: rahayualvifitri@yahoo.co.id
}

Abstract

This writing's the result of research was aimed to explain the effect results of drama script writing skills of using teaching methods Somatic Visual Auditory Intellectual that viewed from student's motivation in class students VIII MTsN Kayu Kalek Kecamatan Lengayang Kabupaten Pesisir Selatan. The research applies quantitative research with experimental method with factorial design. The samples used in this research consist of 60 students which wastaken by using purposive random sampling technique. Data of the research are scores in motivation to learn and scores in drama script writing skills that come from both sample class. There were four results from this research. First, drama script writing skills which was taught by using Somatic Visual Auditory Intellectualmethods wasbetter than students taught by conventional learning. Second, drama script writing skills of students who have high motivation to learn is taught with Somatic Audio Visual Intellectual methods better than drama script writing skills of students who have high learning motivation, which was taught by conventional methods. Third, drama script writing skills of students who have low learning motivation which wastaught by Somatic Audio Visual Intellectual methods was better than drama script writing skills of students who have low learning motivation which was taught by conventional methods. Fourth, there was no interaction between the Somatic Audio Visual Intellectual ( SAVI ) method and the motivation to learn in influencing drama script writing skills. 
Key words: Somatic Audio Visual Intellectual; conventional; writing; drama script

\begin{abstract}
Abstrak
Tulisan ini merupakan hasil penelitian yang bertujuan untuk menjelaskan pengaruh hasil keterampilan menulis naskah drama dengan menggunakan metode pembelajaran Somatic Auditory Visual Intellectual ditinjau dari motivasi belajar siswa kelas VIII MTsN Kayu Kalek Kecamatan Lengayang Kabupaten Pesisir Selatan. Jenis penelitian ini adalah penelitian kuantitatif dengan menggunakan factorial design. Sampel dalam penelitian ini berjumlah 60 dengan menggunakan teknik purposive random sampling. Pengumpulan data dilakukan melalui angket dan tes. Berdasarkan penelitian yang dilakukan dapat disimpulkan empat hal berikut. Pertama, keterampilan menulis naskah drama yang diajarkan dengan menggunakan metode SAVI lebih baik daripada siswa yang diajarkan dengan menggunakan metode konvensional. Kedua, keterampilan menulis naskah drama siswa yang memiliki motivasi belajar tinggi yang diajarkan dengan metode SAVI lebih baik daripada keterampilan menulis naskah drama siswa yang memiliki motivasi belajar tinggi yang diajarkan dengan metode konvensional. Ketiga, keterampilan menulis naskah drama siswa yang memiliki motivasi belajar rendah yang diajarkan dengan metode SAVI lebih baik daripada keterampilan menulis naskah drama siswa yang memiliki motivasi belajar rendah yang diajarkan dengan metode konvensional. Keempat, tidak terdapat interaksi antara metode Somatic Audio Visual Intellectual (SAVI) dengan motivasi belajar dalam mempengaruhi keterampilan menulis naskah drama.
\end{abstract}

Kata Kunci: Somatic Audio Visual Intellectual; konvensional: menulis; naskah drama

\title{
Pendahuluan
}

Belajar merupakan usaha sadar manusia dalam upaya meningkatkan keterampilan, kualitas, dan kuantitas pengetahuan manusia itu sendiri. Dalam proses belajar mengajar di sekolah seringkali kita menjumpai beberapa kendala sehingga tidak tercapainya tujuan pembelajaran (Winkel, 2009:53). Berdasarkan observasi di lapangan, terdapat beberapa kendala yang ditemukan dalam pembelajaran bahasa. Kendala tersebut di antaranya, siswa tidak mampu mencapai tujuan belajar atau hasil belajar sesuai dengan yang tercantum dalam kurikulum bahwa siswa dikatakan lulus atau tuntas dalam suatu pelajaran jika telah memenuhi Kriteria Ketuntasan Minimal (KKM) yang telah ditentukan oleh tiap-tiap guru bidang studi. KKM dibuat berdasarkan intake (pencapaian) siswa di 
dalam kelas. Apabila seorang siswa tidak mencapai kriteria tersebut, maka yang bersangkutan dikatakan bermasalah dalam pelajaran tersebut.

Selanjutnya, berdasarkan observasi di MTsN Kayu Kalek kendala yang ditemukan dalam proses belajar mengajar adalah kurangnya motivasi siswa dalam belajar, yakni keadaan atau kondisi siswa yang kurang bersemangat dalam belajar seperti bermain-main ketika belajar, dan ada juga yang membuat lukisan ketika guru menjelaskan pelajaran. Ketika guru memberi tugas, siswa malas mengerjakannya dan lebih suka mengganggu temannya yang lain. Motivasi belajar sangat berpengaruh pada aktivitas belajar, bila motivasi tersebut lemah, maka hasil belajar akan menjadi rendah. Untuk mengoptimalkan motivasi belajar perlu didukung pula suasana belajar yang menyenangkan.

Kendala dalam proses pembelajaran selanjutnya yaitu, metode pembelajaran yang digunakan guru masih menggunakan metode ceramah, sehingga siswa merasa bosan dan mengantuk di dalam kelas. Dalam proses belajar mengajar, peran guru masih dominan. Siswa lebih diarahkan kepada keterampilan menghafal materi, tanpa memahaminya. Siswa dituntut untuk mengingat informasi dan kurang dituntut memahami informasi tersebut sehingga keterampilan intelektual siswa tidak berkembang. Di kelas siswa lebih sering mencatat materi pelajaran daripada siswa memecahkan sendiri suatu masalah yang ada pada kehidupan sehari-hari.

Salah satu aspek dari keterampilan menulis di sekolah yang harus dikuasai siswa adalah menulis naskah drama. Pada Kurikulum Tingkat Satuan Pendidikan (KTSP) pada jenjang SLTP/MTs pembelajaran menulis naskah drama dapat ditemukan pada kelas VIII semester I (satu) yaitu pada Standar Kompetensi 8 (delapan) mengungkapkan pikiran dan perasaan melalui kegiatan menulis kreatif naskah drama di sekolah yang terdapat pada Kompetensi Dasar 8.1, yaitu menulis kreatif naskah drama satu babak dengan memperhatikan keaslian ide, dan Kompetensi Dasar 8.2, yaitu menulis kreatif naskah drama satu babak dengan memperhatikan kaidah penulisan naskah drama (BNSP, 2016).

Menteri Kebudayaan dan Pendidikan Dasar dan Menengah, Anies Baswedan mengingatkan bahwa keterampilan untuk menulis harus diasah oleh masing-masing anak, apapun cita-cita yang dinginkan anak keterampilan menulis tetaplah sangat penting (Randa, 2014). Berdasarkan pernyataan dari Anies Baswedan tersebut, maka semakin disadari betapa pentingnya keterampilan menulis itu, bahkan di Perguruan Tinggi keterampilan menulislah yang dijadikan puncak tuntutan bagi setiap mahasiswa. Artinya, setiap mahasiswa harus mampu menulis makalah, skripsi, tesis, dan disertasi sesuai dengan jenjang pendidikan yang diikuti. 
Namun memprihatinkan sekali, budaya membaca dan menulis masyarakat Indonesia sekarang jauh menurun jika dibandingkan dengan masa penjajahan Belanda. Penyair Indonesia Taufik Ismail ketika mendapat anugerah Habibie Award 2007 untuk bidang budaya mengatakan bahwa siswa setingkat SMA di masa penjajahan Belanda, selama tiga tahun sekolahnya, wajib membuat 106 tulisan dan membaca 25 buku sastra yang terdiri atas empat bahasa yaitu bahasa Inggris, Belanda, Jerman, dan Perancis. Kenyataannya sekarang memprihatinkan sekali, siswa SMA rata-rata hanya membuat satu tulisan dalam satu tahun (Sutawi, 2015). Berdasarkan fakta yang terjadi pada saat ini, kita sadari betapa pentingnya melatih siswa menulis sejak bangku Sekolah Dasar agar mereka terbiasa dengan aktivitas menulis.

Pembelajaran menulis naskah drama akan berhasil, jika pada diri siswa ada keinginan untuk menulis naskah drama. Keinginan atau dorongan inilah yang disebut dengan motivasi.Hal tersebut senada dengan pendapat Slavin (2009:177) yang menjelaskan bahwa motivasi merupakan faktor penting dalam pembelajaran sekaligus sebagai penentu kegiatan belajar yang dilakukan. Motivasi belajar dapat diamati dari kegiatan dan hasil belajarnya. Siswa yang memperoleh hasil belajar yang baik karena kegigihannya menunjukkan motivasi belajar yang tinggi. Siswa yang memperoleh hasil belajar yang rendah dapat pula disebabkan oleh motivasi belajar yang rendah.Dari permasalahan yang telah dijelaskan di atas, maka motivasi memberikan pengaruh pada keterampilan siswa dalam menulis naskah drama.

Pada umumnya pembelajaran menulis naskah drama di sekolah masih menggunakan metode konvensional, sehingga siswa merasa jenuh dengan metode belajar yang statis dan hanya mendengarkan ceramah dari guru. Hal tersebut dirasakan kurang efektif dirasakan karena guru lebih dominan serta guru hanya banyak menjelaskan hal-hal yang sifatnya umum yang sifatnya teori sehingga siswa kurang memahami pembelajaran drama serta penulisan drama. Sebaiknya pembelajaran drama disampaikan dengan metode yang berpusat pada siswa, sehingga siswa bisa dapat memahami serta merasakan pengalaman dalam pembelajaran berdasarkan peristiwa yang dialami dalam kehidupan sehari-hari.

Berdasarkan kesulitan yang ditemukan guru dalam pembelajaran menulis, khususnya menulis kreatif drama, untuk itu guru merancang dan menerapkan berbagai metode pembelajaran, sehingga tujuan membelajaran dapat tercapai. Untuk menjawab permasalahan di atas, maka metode SAVI merupakan metode yang tepat digunakan dalam menulis naskah drama. Hal ini disebabkan karena metode SAVI adalah metode yang berpusat pada siswa karena dalam pembelajaran melibatkan seluruh anggota tubuh. Pada

\section{UNP JOURNALS}


pembelajaran SAVI tidak lagi berpusat pada guru, tetapi siswa yang aktif dalam pembelajaran menulis drama, sehingga mereka dapat menulis drama berdasarkan pengalaman yang telah mereka alami sendiri atau berdasarkan pengalaman orang lain yang pernah mereka temukan dalam kehidupan seharihari.

Pembelajaran dengan menggunakan pendekatan SAVI yaitu menggabungkan gerakan fisik dengan aktivitas intelektual, dan penggunaan semua indera dalam satu peristiwa pembelajaran (Dave Meier, 2002:91). Dalam pembelajaran yang berpola pendekatan SAVI, siswa melakukan beberapa aktivitas belajar seperti, belajar dengan bergerak dan berbuat, belajar dengan berbicara dan mendengar, belajar dengan melihat, mengamati, membaca dan menggambarkan, serta belajar dengan memecahkan masalah. Dengan menggunakan pendekatan SAVI dalam pembelajaran dapat membantu memunculkan suasana belajar yang lebih baik, menarik, dan efektif. Hal tersebut dikarenakan pembelajaran dengan pendekatan SAVI menggunakan permainan, mampu membangkitkan kreativitas dan meningkatkan keterampilan psikomotor siswa dan memaksimalkan ketajaman konsentrasi siswa melalui pembelajaran secara visual, auditori dan intelektual. Metode pembelajaran (SAVI) diharapkan dapat dimanfaat untuk mengatasi kesulitan guru dalam pembelajaran menulis naskah drama, dengan menggunakan metode ini dapat meningkatkan keterampilan menulis siswa. Metode SAVI dapat membantu dalam peningkatan motivasi belajar dan keterampilan menulis naskah drama siswa, sehingga keterampilan menulis naskah drama siswa dapat lebih baik dari sebelumnya.

Penelitian dengan menggunakan SAVI telah banyak dilakukan, salah satunya oleh Teti Milawati (2011) hasil observasi selama penerapan pembelajaran SAVI berlangsung sangat baik. Hal ini terlihat dari nilai persentase yang diperoleh $94 \%$ terhadap penilaian aktivitas siswa dan $96 \%$ hasil aktivitas guru dalam kelas. Nilai ini menandakan bahwa aktivitas siswa dan guru dalam setiap pertemuan di kelas eksperimen sangat baik. Hasil penelitian Dian Hirdaniati Safitri (2014) keterampilan menulis cerpen berdasarkan pengalaman orang lain siswa setelah digunakannya metode SAVI hasil belajar tergolong baik dengan nilai rata-rata 77,18 dengan nilai tertinggi 90,47 dan nilai terendah 61,9 SAVI memberi pengaruh yang signifikan dalam pembelajaran menulis cerpen berdasarkan pengalaman orang lain. Selanjutnya penelitian yang dilakukan oleh Indah Fajrina (2014), hasil penelitian diperoleh dengan menggunakan metode SAVI dengan rata-rata 80,3 sedangkan menggunakan Ekspositori dengan 
nilai rata-rata 64,5. SAVI lebih berpengaruh daripada Ekspositori terhadap meningkatkan keterampilan siswa dalam bermain drama.

Dari permasalahan yang telah dijelaskan di atas, maka motivasi belajar memberikan pengaruh pada keterampilan siswa dalam menulis naskah drama. Selain itu, motivasi juga erat kaitannya dengan menulis naskah drama siswa, tanpa adanya motivasi maka sebuah drama tidak dapat tercipta. Untuk menjawab permasalahan di atas, maka metode SAVI merupakan metode yang tepat digunakan dalam menulis naskah drama. Hal ini dapat dilihat bahwa metode pembelajaran SAVI dapat digunakan untuk merangsang siswa dalam menulis naskah drama. Penerapan metode SAVI ini, diharapkan dapat memberikan pembaharuan dalam proses pembelajaran menulis naskah drama siswa, sehingga mampu meningkatkan minat, motivasi, serta keterampilan menulis siswa. Sama halnya dengat motivasi yang dimiliki siswa diharapkan dapat berpengaruh terhadap keterampilan menulis naskah drama siswa. Jadi, berdasarkan fenomena serta uraian yang telah dipaparkan tersebut, dapat disimpulkan bahwa penelitian ini penting untuk dilaksanakan.

\section{Metodologi Penelitian}

Jenis penelitian ini adalah penelitian kuantitatif. Menurut Arikunto (2006:27) dalam penelitian kuantitatif dituntut untuk menggunakan angka, mulai dari pengumpulan data, serta penyimpulan.Penelitian ini dilakukan dengan menggunakan metode eksperimen semu (quasi exsperiment), yaitu penelitian yang bertujuan untuk memperoleh informasi dari eksperimen berdasarkan perlakuan (treatment) terhadap suatu unit percobaan dalam batas-batas desain yang ditetapkan pada kelas eksperimen sehingga diperoleh data yang menggambarkan apa yang diharapkan. Menurut Sugiyono (2006:86), quasi eksperiment digunakan karena pada kenyataannya sulit mendapatkan kelompok kontrol yang dapat digunakan untuk penelitian (tidak variabel-variabel yang mempengaruhi pelaksanaan eksperimen), kelas eksperimen diberikan perlakuan dengan menggunakan metode SAVI sedangkan pada kelas kontrol menggunakan metode pembelajaran konvensional. Desain penelitian yang digunakan adalah factorial design, dalam penelitian ini akan dilihat pengaruh dari penggunaan metode Somatic Auditori Visual Intellectual terhadap keterampilan menulis naskah drama.

Penelitian dilaksanakan di MTsN Kayu Kalek Kecamatan Lengayang Kabupaten Pesisir Selatan. Penelitian dilaksanakan pada semester ganjil tahun pelajaran 2015/2016, yaitu bulan Desember sampai bulan Maret. Pengambilan sampel dilakukan dengan teknik purposive random sampling, yaitu pengambilan

\section{UNP JOURNALS}

ISSN 1411-3732 
sampel berdasarkan pertimbangan tertentu dalam menetapkan kelas eksperimen dan kelas kontrol. Sampel yang dijadikan kelas eksperimen adalah kelas VIII.5 dan kelas kontrol adalah kelas VIII.4 berdasarkan pengundian dengan lot.

Penelitian ini terdiri dari tiga variabel. Pertama, variabel independen (variabel bebas) adalah variabel yang menyebabkan perubahan terhadap variabel dependen.Variabel independen dalam penelitian ini adalah metode Somatic Auditori Visual Intellectual. Kedua, variabel dependen (variabel terikat) adalah variabel yang dipengaruhi oleh variabel independen. Dalam penelitian ini variabel dependen adalah keterampilan menulis naskah drama. Ketiga, variabel moderator adalah variabel yang memperkuat hubungan antara variabel independen dan dependen. Berperan sebagai variabel moderator dalam penelitian ini adalah motivasi belajar.

Data penelitian ini sebagai berikut, (1) skor hasil tes keterampilan menulis naskah drama siswa dengan menggunakan metode Somatic Auditori Visual Intellectual dan konvensional, (2) skor hasil tes keterampilan menulis siswa yang memiliki motivasi tinggi dan motivasi rendah dengan menggunakan metode Somatic Auditori Visual Intellectual, (3) skor hasil tes keterampilan menulis siswa yang memiliki motivasi tinggi dan motivasi rendah dengan menggunakan metode konvensional.

Secara umum, prosedur penelitian dibagi menjadi tiga tahap yaitu persiapan, pelaksanaan, dan evaluasi.Instrumen penelitian disusun berdasarkan teori yang ada dan disesuaikan dengan indikator yang menunjang penelitian ini. Langkah-langkah dalam menyusun instrumen tes sebagai berikut. Pertama, pembuatan kisi-kisi berdasarkan indikator tes. Kedua, penyusunan soal angket dan unjuk kerja berdasarkan indikator tes. Ketiga, melakukan analisis rasional untuk melihat kesesuaian soal angket dan unjuk kerja dengan aspek yang diukur.Instrumen yang digunakan untuk mengumpulkan data dalam penelitian ini adalah angket dan tes unjuk kerja.

Sesuai dengan teknik pengumpulan data yang dilakukan, sistematika penganalisisan data dalam penelitian dilakukan dengan dua bagian, yaitu analisis angket dan kinerja. Teknik menganalisis angket dapat dilakukan dengan cara sebagai berikut. Pertama, membaca angket yang telah diisi siswa. Kedua, mengidentifikasikan setiap pertanyaan yang terdapat dalam angket apakah ada yang tidak diisi oleh siswa, kalau seandainya ada yang tidak diisi tidak masuk ke dalam data penelitian. Ketiga, memberi skor pada setiap pernyataan angket yang telah diidentifikasikan. Keempat, menjumlahkan keseluruhan skor pernyataan. Kelima, mengurutkan skor angket mulai dari skor tertinggi sampai ke skor 
terendah. Keenam, membagi motivasi belajar siswa menjadi kelompok motivasi belajar tinggi dan kelompok motivasi belajar rendah dengan ketentuan $50 \%$ ke atas termasuk pada kategori tinggi dan $50 \%$ ke bawah termasuk pada kategori rendah (Arikunto, 2008:216).

Data penelitian ini berasal dari nilai siswa dalam menulis naskah drama menggunakan metode SAVI. Pertama, membaca tulisan drama siswa secara keseluruhan. Kedua, mengidentifikasi data apakah sesuai dengan data penelitian atau tidak. Ketiga, memberikan skor pada tulisan tersebut sesuai dengan indikator yang diteliti. Keempat, mengubah skor menjadi nilai berdasarkan PAP (Penilaian Acuan Patokan). Kelima, pemberian makna skor siswa dengan cara membandingkan hasil belajar siswa dengan hasil belajar siswa lainnya dalam satu kelompok (Arifin, 2011: 240). Selanjutnya, analisis data hasil penelitian ini menggunakan metode statistik untuk melihat keterampilan menulis naskah drama siswa kelas VIII MTsN Kayu Kalek. Data dianalisis menggunakan uji perbedaan dua rata-rata. dengan uji normalitas dan homogenitas dari data yang diperoleh.

\section{Pembahasan}

Hasil keterampilan menulis naskah drama siswa kelas VIII MTsN Kayu Kalek yang diteliti menunjukkan bahwa siswa yang diajar dengan metode Somatic Audio Visual Intellectual lebih baik daripada yang diajar menggunakan metode konvensional, baik untuk kelompok siswa yang memiliki motivasi tinggi, maupun kelompok siswa yang memiliki motivasi rendah. Hal tersebut disebabkan pembelajaran dengan menggunakan metode SAVI lebih menarik dan tidak monoton karena melibatkan seluruh anggota tubuh siswa. Hal ini sejalan dengan pendapat Meier (2002:90) bahwa belajar SAVI adalah belajar berdasarkan aktivitas yang berarti bahwa bergerak aktif secara fisik ketika belajar, dengan memanfaatkan indera sebanyak mungkin, dan membuat seluruh tubuh dan pikiran terlibat dalam proses belajar. Secara empiris, hal ini terbukti dari hasil uji hipotesis yang telah dikemukakan di atas. Berdasarkan hasil uji hipotesis tersebut akan dilakukan pembahasan. Pembahasannya dikaitkan dengan teori yang telah dikemukankan pada bagian terdahulu.

Hasil pengujian hipotesis pertama mengungkapkan bahwa secara keseluruhan, Keterampilan menulis naskah drama siswa yang diajar dengan metode Somatic Audio Visual Intellectual (SAVI) lebih baik daripada Keterampilan menulis naskah drama siswa yang diajar dengan metode konvensional. Hal ini terlihat dari pengujian hipotesis yang menunjukkan bahwa pada taraf nyata 0,05 $t_{\text {hitung }}=3,60>t_{\text {tabel }}=1,67$.

\section{UNP JOURNALS}

ISSN 1411-3732 
Metode Somatic Audio Visual Intellectual (SAVI) mengkondisikan siswa dalam bentuk kelompok yang heterogen dilihat dari berbagai segi kemampuan akademik. Kelompok atau team yang dibentuk bertujuan untuk memudahkan siswa mendiskusikan permasalahan yang ditemukan dalam proses pembelajaran. Hal ini sesuai dengan pendapat Asma (2012:3), "Kegiatan siswa dalam dalam belajar kooperatif antara lain mengikuti penjelasan guru secara aktif, menyelesaikan tugas dalam kelompok, memberikan penjelasan pada teman sekelompoknya, mendorong teman sekelompok untuk berpartisipasi secara aktif, dan berdiskusi".

Penerapan metode Somatic Audio Visual Intellectual (SAVI) dapat membantu siswa dalam memahami konsep-konsep, teori-teori, sistematika, dan ketentuan lain dengan cara yang mudah. Dalam kegiatan pembelajaran siswa dapat saling bertukar pikiran dan membahas masalah secara bersama-sama karena dalam proses pembelajaran menggunakan metode SAVI ini siswa dibagi menjadi beberapa kelompok kecil. Dalam kegiatan pembelajaran SAVI terdapat empat tahapan yang terdiri dari tahap persiapan (kegiatan pendahuluan), tahap penyampaian (kegiatan inti), tahap pelatihan (kegiatan inti), dan tahap penampilan hasil (kegiatan penutup).

Tes yang diberikan kepada siswa adalah tes unjuk kerja, yaitu tes menulis naskah drama yang dilakukan di kelas eksperimen dan kelas kontrol. Bentuk tes yang diberikan kepada kedua kelas tersebut sama, yang membedakan adalah pada kelas eksperimen siswa terlebih dahulu dirangsang secara emosional dengan ditayangkan video, kemudian berdasarkan video tersebut, siswa secara berkelompok mendiskusikan kerangka drama, kemudian masing-masing siswa menulis kerangka drama tersebut. Berdasarkan kerangka drama yang telah didiskusikan siswa dalam kelompok, selanjutnya secara individu siswa dapat mengembangkan kerangka drama tersebut menjadi naskah drama yang utuh, terdiri dari prolog, dialog, dan epilog. Pada kelas kontrol, siswa hanya diberikan ilustrasi saja tanpa ditayangkan video, selanjutnya siswa diberi waktu untuk memikirkan kerangka drama dari ilustrasi yang telah diberikan guru. Setelah menemukan kerangka drama, siswa mengembangkan kerangka drama menjadi naskah drama yang utuh, terdiri dari prolog, dialog, dan epilog. Tes ini dilakukan untuk melihat pengaruh metode Somatic Audio Visual Intellectual (SAVI) terhadap keterampilan menulis teks naskah drama siswa di kelas VIII MTsN Kayu Kalek Kabupaten Pesisir Selatan Kecamatan Lengayang.

Hasil tes keterampilan menulis naskah drama siswa pada kelas eksperimen cukup bervariasi menunjukkan bahwa siswa mampu menulis naskah drama. Hal ini terlihat dari nilai rata-rata yang diperoleh oleh kelas eksperimen 
lebih baik daripada kelas kontrol sebesar 82,12. Angka ini menunjukkan bahwa kemampuan rata-rata siswa kelas eksperimen dalam menulis naskah drama sudah berada di atas KKM yang telah ditetapkan oleh sekolah, yaitu 78. Siswa kelas eksperimen sudah mampu menulis naskah drama dengan baik, hal ini terlihat dari aspek yang dinilai seperti, keterampilan memberi judul, penggambaran tokoh/perwatakan, penggambaran latar dan petunjuk teknis, keterampilan membuka, mengembangkan, serta menutup dialog, dan bahasa sudah mampu dideskripsikan dengan jelas dan menarik.

Berbeda dengan metode Somatic Audio Visual Intellectual (SAVI), metode konvensional menempatkan siswa sebagai objek belajar yang berperan sebagai objek penerima yang pasif. Siswa hanya menerima informasi yang diberikan oleh sumber belajar atau guru. Pada umumnya, metode konvensional menerapkan metode ceramah, tanya jawab, dan penugasan. Hal ini sesuai dengan pendapat Djafar (2001:3) yang mengatakan bahwa metode konvensional merupakan metode yang beriorentasi pada guru sehingga hampir seluruh kegiatan belajar mengajar dikendalikan oleh guru. Sangat sedikit kesempatan siswa untuk memberikan kontribusi terhadap pengetahuan, keterampilan, dan sikap dalam proses pembelajaran. Siswa yang diajar dengan metode konvensional cenderung tidak kreatif, kurang mandiri, harus selalu dibantu, dan tidak terbiasa menemukan sendiri. Hal ini mengakibatkan siswa malas dan tidak termotivasi untuk mencipta dan menghasilkan sebuah tulisan.

Hasil tes keterampilan menulis naskah drama siswa pada kelas kontrol menunjukkan bahwa siswa kurang mampu menulis naskah drama. Hal ini terlihat dari nilai rata-rata yang diperoleh oleh kelas kontrol sebesar 74,55. Angka ini menunjukkan bahwa kemampuan rata-rata siswa kelas kontrol dalam menulis naskah drama masih berada di bawah KKM yang telah ditetapkan oleh sekolah, yaitu 78. Siswa kelas kontrol kurang mampu menulis naskah drama dengan baik. Hal ini terlihat dari aspek yang dinilai seperti, keterampilan memberi judul, penggambaran tokoh/perwatakan, penggambaran latar dan petunjuk teknis, keterampilan membuka, mengembangkan, serta menutup dialog, dan bahasa tidak mampu dideskripsikan dengan jelas dan menarik.

Pengujian hipotesis kedua menunjukkan hasil yang menyatakan bahwa secara umum, keterampila menulis naskah drama siswa bermotivasi belajar tinggi pada kelas eksperimen yang diajar dengan metode Somatic Audio Visual Intellectual (SAVI) lebih baik daripada keterampilan menulis naskah drama siswa bermotivasi belajar tinggi pada kelas kontrol yang diajar dengan metode konvensional. Hal ini terlihat dari hasil penghitungan uji hipotesis yang 
menunjukkan $t_{\text {hitung }}=2,26>t_{\text {tabel }}=1,70$ pada taraf nyata 0,05 . Hasil penghitungan tersebut menunjukkan bahwa $\mathrm{H}_{1}$ diterima karena $t_{\text {hitung }}>\mathrm{t}_{\text {tabel. }}$

Pembelajaran menggunakan metode Somatic Audio Visual Intellectual mampu meningkatkan keterampilan menulis naskah drama siswa yang memiliki motivasi tinggi. Hal ini disebabkan karena siswa yang memiliki motivasi tinggi memiliki pengetahuan tentang drama yang mereka peroleh dari bahan bacaan mereka, sehingga dapat membantu siswa tersebut dalam mengikuti semua tahapan pembelajaran menggunakan metode Somatic Audio Visual Intellectual.

Pengujian hipotesis ketiga menunjukkan hasil yang nyata bahwa secara umum, keterampilan menulis naskah drama siswa bermotivasi belajar rendah pada kelas eksperimen yang diajar dengan metode SAVIlebih baik daripada keterampilan menulis naskah drama siswa bermotivasi belajar rendah pada kelas kontrol yang diajar dengan metode konvensional. Hal ini terlihat dari hasil penghitungan uji hipotesis yang menunjukkan $t_{\text {hitung }}=3,38>t_{\text {tabel }}=1,70$ pada taraf nyata 0,05 . Hasil penghitungan tersebut menunjukkan bahwa $\mathrm{H}_{1}$ diterima karena thitung $>t_{\text {tabel. }}$

Metode SAVI mampu meningkatkan keterampilan menulis naskah drama siswa bermotivasi belajar rendah. Dalam pembelajaran dengan metode SAVI siswa dibagi menjadi beberapa kelompok, siswa diberi kebebasan untuk mengemukakan pendapat, pikiran, dan pertanyaan terhadap permasalahan yang ditemukan dalam belajar. Siswa yang awalnya kurang memiliki motivasi dalam menulis naskah drama dapat terbantu oleh dukungan yang diberikan oleh kelompok. Disamping itu, dengan menayangkan video dan mengidentifikasi kerangka drama tersebut akan memudahkan siswa dalam proses menulis naskah drama.

Suatu interaksi terjadi manakala efek faktor yang satu tergantung pada faktor lain dalam mempengaruhi sesuatu. Hal ini berarti bahwa masing-masing faktor antara metode pembelajaran SAVI dan Konvensional dengan motivasi belajar saling tergantung satu sama lainnya dalam mempengaruhi keterampilan menulis naskah drama siswa. Hal ini senada dengan pendapat Irianto (2014:225) yang menyatakan bahwa interaksi terjadi apabila efek faktor yang satu tergantung pada faktor yang lainnya dalam mempengaruhi sesuatu. Hal ini berarti bahwa masing-masing faktor antara metode Somatic Audio Visual Intellectual dan motivasi saling tergantung satu sama lainnya dalam mempengaruhi keterampilan menulis naskah drama siswa. Proses interaksi antara variabel-variabel tersebut dapat dijelaskan sebagai berikut.

Hasil penghitungan anava dua arah untuk pengujian hipotesis keempat dapat disimpulkan bahwa tidak terdapat interaksi antara metode Somatic Audio 
Visual Intellectual dengan motivasi dalam mempengaruhi keterampilan menulis naskah drama. Sebagaimana yang telah dikemukakan sebelumnya, interaksi merupakan efek perlakuan metode pembelajaran tertentu terhadap kelompok siswa yang memiliki motivasi tertentu. Namun, motivasi belum tentu sepenuhnya menentukan keberhasilan dalam keterampilan menulis naskah drama. Banyak faktor lain sebagai penunjang seperti intelegensi, kemampuan, bakat, dan lainnya. Selain itu faktor kesiapan guru dalam menggunakan metode Somatic Audio Visual Intellectual dalam proses pembelajaran menulis naskah drama juga akan berpengaruh terhadap keterampilan menulis naskah drama siswa.

Tidak terdapat interaksi antara metode Somatic Audio Visual Intellectual dengan motivasi juga dapat dilihat dari rata-rata nilai keterampilan menulis naskah drama. Hal tersebut terjadi pada kedua tingkatan motivasi, baik tinggi maupun rendah yang sama-sama diajar menggunakan metode Somatic Audio Visual Intellectual. Rata-rata nilai keterampilan menulis naskah drama siswa yang mempunyai motivasi tinggi dan rendah di kelas eksperimen lebih tinggi daripada siswa yang memiliki motivasi tinggi dan rendah di kelas kontrol. Dapat disimpulkan bahwa masing-masing faktor dari metode dan motivasi tidak saling bergantung satu sama lainnya dalam mempengaruhi hasil keterampilan menulis naskah drama kelas eksperimen dan kelas kontrol. Walaupun demikian, metode Somatic Audio Visual Intellectual terlihat lebih efektif diterapkan pada kedua tingkatan motivasi tersebut. Dengan kata lain, metode Somatic Audio Visual Intellectual dapat diterapkan untuk siswa yang memiliki motivasi tinggi dan dapat juga diterapkan untuk siswa yang memiliki motivasi rendah.

\section{Simpulan dan Saran}

Penelitian ini membahas tentang pengaruh penggunaan metode Somatic Audio Visual Intellectual dan motivasi belajar terhadap keterampilan menulis naskah drama siswa kelas VIII MTsN Kayu Kalek Kecamatan Lengayang Kabupaten Pesisir Selatan. Berdasarkan deskripsi, analisis, dan pembahasan terhadap data penelitian yang telah dilakukan, hasil penelitian ini dapat disimpulkan sebagai berikut.

Pertama, keterampilan menulis naskah drama yang diajarkan dengan menggunakan metode Somatic Audio Visual Intellectual lebih baik daripada siswa yang diajarkan dengan menggunakan metode konvensional siswa kelas VIII MTsN Kayu Kalek Kecamatan Lengayang Kabupaten Pesisir Selatan. Temuan penelitian ini menunjukkan bahwa metode Somatic Audio Visual Intellectual memberikan pengaruh terhadap hasil menulis naskah drama siswa. Hal ini disebabkan oleh

\section{UNP JOURNALS}

ISSN 1411-3732 
keterlibatan intelektual emosional siswa yang lebih tinggi dalam kegiatan pembelajaran. Keterlibatan tersebut terjadi pada kegiatan kognitif dalam pencapaian dan perolehan, sehingga dapat membantu siswa dalam mencapai tujuan pembelajaran yang sesuai dengan kemampuan yang diharapkan. Oleh sebab itu, guru dapat menerapkan metode Somatic Audio Visual Intellectual ini pada pembelajaran di sekolah, agar dapat memperbaiki dan meningkatkan keterampilan menulis naskah drama siswa.

Kedua, keterampilan menulis naskah drama siswa yang memiliki motivasi belajar tinggi yang diajarkan dengan metode Somatic Audio Visual Intellectual lebih baik daripada keterampilan menulis naskah drama siswa yang memiliki motivasi belajar tinggi yang diajarkan dengan metode konvensional. Temuan penelitian ini menunjukkan bahwa semakin tinggi motivasi belajar siswa maka dapat mempermudah siswa dalam mengeluarkan ide, gagasan, dan imajinasi mereka dalam bentuk tulisan. Penggunaan metode Somatic Audio Visual Intellectual juga memberikan pengaruh terhadap hasil belajar menulis naskah drama siswa. Oleh karena itu, guru harus memperhatikan motivasi belajar dan dapat menerapkan metode Somatic Audio Visual Intellectual pada pembelajaran bahasa Indonesia di sekolah, agar dapat meningkatkan keterampilan menulis naskah drama siswa.

Ketiga, keterampilan menulis naskah drama siswa yang memiliki motivasi belajar rendah yang diajarkan dengan metode Somatic Audio Visual Intellectual lebih baik daripada keterampilan menulis naskah drama siswa yang memiliki motivasi belajar rendah yang diajarkan dengan metode konvensional. Temuan penelitian ini menunjukkan bahwa motivasi belajar secara tidak langsung mempengaruhi kemampuan keterampilan menulis naskah drama siswa. Akan tetapi untuk membentuk motivasi belajar ini diperlukan waktu yang relatif lama. Selain itu, faktor keinginan dan kemauan sangat diperlukan. Faktor keinginan dan kemauan ini juga harus diperkuat oleh motivasi yang timbul dari dalam maupun dari luar diri individu siswa. Selain itu, penggunaan yang menarik dan mudah dipahami siswa, dapat membangkitkan kreativitas siswa. Hal ini akan memberikan dampak positif bagi proses pembelajaran terutama menulis naskah drama.

Keempat, tidak terdaat interaksi antara metode Somatic Audio Visual Intellectual (SAVI) dengan motivasi belajar dalam mempengaruhi keterampilan menulis naskah drama. Temuan dalam penelitian ini menunjukkan bahwa siswa yang memiliki motivasi belajar tinggi maupun siswa yang memiliki motivasi belajar rendah, apabila diajar dengan metode Somatic Audio Visual Intellectual maka tidak memberikan pengaruh terhadap hasil keterampilan menulis naskah 
rama pada kelas eksperimen dan kelas kontrol. Walaupun demikian, metode Somatic Audio Visual Intellectual tepat diterapkan untuk siswa yang memiliki motivasi belajar tinggi dan tepat diterapkan pada siswa yang memiliki motivasi belajar rendah. Dengan kata lain, metode Somatic Audio Visual Intellectual terlihat lebih efektif diterapkan pada kedua tingkatan motivasi belajar tersebut.

Berdasarkan kesimpulan yang dikemukakan di atas terbukti bahwa metode Somatic Audio Visual Intellectual dan motivasi belajar dapat meningkatatkan keterampilan menulis naskah drama, untuk itu penulis mengemukakan saran sebagai berikut. Pertama, guru mata pelajaran bahasa Indonesia supaya menerapkan metode Somatic Audio Visual Intellectual pada pembelajaran bahasa Indonesia di sekolah, terutama guru-guru bahasa Indonesia MTsN Kayu Kalek Kabupaten Pesisir Selatan Kecamatan Lengayang untuk dapat memperbaiki dan meningkatkan kemampuan menulis naskah drama siswa. Kedua, untuk peneliti lebih lanjut, peneliti selanjutnya agar meneliti lebih mendalam tentang penggunaan metode Somatic Audio Visual Intellectual ini pada pokok bahasan lain atau mata pelajaran lain.Ketiga, bagi siswa, bahwa metode Somatic Audio Visual Intellectual ini memberikan pengaruh yang positif dan lebih baik lagi bagi masing-masing individu maupun bagi siswa dalam proses pembelajaran berkelompok.

Catatan: Artikel ini ditulis berdasarkan hasil penelitian untuk penulisan tesis penulis dengan Pembimbing I Prof. Dr. Atmazaki, M.Pd. dan Pembimbing II Dr. Abdurahman, M.Pd.

\section{Daftar Rujukan}

Asma, Nur. 2012. Model Pembelajaran Kooperatif. Padang: UNP Press.

Arifin, Zainal. 2011. Evaluasi Pembelajaran. Bandung: PT Remaja Rosdakarya.

Arikunto, Suharsimi. 2006. Prosedur Penelitian SuatuPendekatan Praktik. Jakarta: PT Rineka Cipta.

Budiyanto, Agus. 2013. Penerapan Pendekatan Somatic Auditory Visual Intelegency (SAVI) dengan Media Audio Visual untuk Meningkatkan Kualitas Pembelajaran PKn pada Siswa Kelas IV A SD Hj. Isriati Baiturrahman 1 Semarang. Jurnal Pendidikan (Online). Semarang:Universitas Negeri Semarang. Diakses pada 5 desember 2015. 


\section{Komposisi: Jurnal Pendidikan $\mid$ Volume XVII No. 1 Bahasa, Sastra, dan Seni Maret 2016}

Bunga. 2015. "Pengaruh Pembelajaran Kooperatif dengan TTW dan Motivasi Belajar terhadap Keterampilan Menulis naskah Drama pada Siswa Kelas VIII SMP Negeri 3 Batang Anai". Dalam Jurnal Pendidikan(Online). Padang: Universitas Negeri Padang. Diakses pada 5 desember 2015.

Djafar, Teuku Zahara.2001. kontribusi Strategi Pembelajaran terhadap Hasil Belajar. Padang. FIP UNP.

Irianto, Agus. 2004. Statistik Konsep Dasar dan Aplikasinya. Jakarta: Perdana Media.

Kusumawati, Sri Wahyuni. 2013. "Penerapan Model Pembelajaran SAVI UntukMeningkatkan KeterampilanPemecahan Masalah di Sekolah Dasar". Jurnal Pendidikan (Online)Volume 01 Nomor 02Tahun 2013. Surabaya: Universitas Negeri Surabaya. Diakses pada pada 5 Maret 2016.

Meier, Dave. 2002. The Accelerated Learning; Handbook (diterjemahkan oleh: Rahmani Astuti).Bandung: Kaifa.

Milawati, Teti. 2011. "Peningkatan Keterampilan Anak Memahami Drama dan Menulis Teks Drama Melalui Pembelajaran Somatis Auditori Visual Intelektual (SAVI)". Jurnal PendidikanEdisi Khusus Nomor 2, Agustus 2011.Diakses pada 5 Maret 2016.

Sardiman. 2010. Interaksi dan Motivasi Belajar Mengajar. Jakarta: Rajawali Pers.

Safitri, Dian Hirdaniati. 2014. "Keterampilan Menulis Cerpen berdasarkan pengalaman orang lain pada siswa kelas X SMA Negeri 15 Medan". Jurnal Pendidikanl. (Online). Medan: Universitas Negeri Medan. Diakses pada 17 Maret 2016.

Slavin, Robert E. 2009.Cooperative Learning: Teori, Riset, dan Praktik. Bandung: Nusa Media.

Sutawi. 2015. "Aku Menulis, Maka Aku Ada!". (Online). (Sutawi.staff.umm.ac.id>blog_article_190). (Diakses 15 Oktober 2015)

Sugiyono. 2009. Metode Penelitian Pendidikan. Bandung: CV Alfabeta.

Winkel, WS. 2009. Psikologi Pengajaran. Yogyakarta: Media Abadi. 